search Organisation. It consists of an Executive of five members and of the officers comprising the staff. The Executive is the governing body. Its members will be appointed by the Governor-General, and at least three of them are to possess scientific qualifications. The chairman and two others will devote the whole of their time to the duties of office. Whereas the former Council carried sole responsibility for the scientific programme placed before the Government, provision is now made for political initiation of work, it being the duty of the Organisation to exercise its powers and functions in relation to any matter referred to it by its minister. In the important matter of staff, while the Executive may appoint such officers and employ such temporary or casual employees as it thinks necessary for the purposes of the Act, it is in each case subject to the specific direction that "the selection of persons... shall be made in accordance with such requirements as the Public Service Board determines". So, too, terms and conditions are in all cases "subject to the approval of the Public Service Board". Also, the maximum number of officers and employees whose duties are primarily of an administrative or clerical nature is similarly subject to the Board's approval. Under the earlier Act, the Council and minister settled these matters, independently of the Public Service Board. A somewhat cryptic clause towards the end of the Act runs: "A member of the Executive, a member of the Advisory Council, a member of a State Committee, an officer or an employee shall not, except in the course of his duty as such a member, officer or employee or with the approval of the Executive, disclose any information concerning the work of the Organisation or the contents of any document in the possession of the Organisation. Penalty : Imprisonment for two years." The opportunity has been taken also to effect certain minor changes which experience has shown to be desirable; but it is difficult at this stage to predict just how the new legislation as a whole will aftect established scientific activities. The sequel need not be unsatisfactory; but it is known that in some quarters the position $f$ is regarded with a measure of anxiety.

\section{Progress in Educaition}

IN his preside tial address to the National Union of Teachers at Margate on April 16, Mr. I. Gwynne Rees, of R. Talbot, outlined the extent to which the 1944 ducation Act has already been implementedX Two years ago, at a time of unprecedented diffculties, school life for every pupil in Britain was expentled to the age of fifteen. The number of teachers in primary and secondary schools is now 10 per cent greater than before the War, while the average number of pupils per teacher in the primary and secondary schools has been reduced by about 6 per cent; in the primary school, however, the average class still remains nearly 50 per cent larger than in the secondary school. These reforms, said Mr. Rees, have been made possible by the rapid increase in the supply of well-qualified teachers, provision having already been made for the training of 66 per cent more students in the permanent colleges and 44 per cent more in the universities than before the War. The other major reform necessary for the reduction in the size of classes is, he said, the provision of sufficient classrooms. In 1948 work in progress involved an ultimate capital expenditure of $£ 23,000,000$, and in 1949 the figure would be $£ 55,000,000$. There has also been remarkable pro- gress in the facilities for higher education. The toll-gate of school fees has been removed, and State scholarships and local education authority awards for further education have doubled in number since 1939. In the earlier stages of education, particular concern is being felt for the infant and junior schools, where the handicapping of the less gifted begins through lack of suitable equipment and through classes of forty, fifty and even sixty children. This seventy. fourth Conference of the National Union of Teachers was distinguished, for the first time, by the presence of the Prime Minister. In an inspiring address, Mir. Attlee declared that the prime duty of all teachers is to train their pupils to become good citizens of a democratic society.

\section{ISI Bulletin}

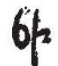

A NEW quarterly jornal, ISI Bulletin, has been issued by the Indi N Nandards Institution, $P$ Block, Raisina Road, Delhi. The price is $2 s$, and the first number ntains thirty-six pages. The Indian Standares Institution was founded in 1947, primarily as) an industrial organisation, but with Government sufport. The president is Dr. S. P. Mookerjee, Mind ter for Industry and Supply, and its director, Dr. Lal C. Verman. It has set up four executive committees for agricultural products, documentation, quality control and industrial statistics, and weights and measures, together with engineering, textile and chemical division councils, sponsoring a total of 118 committees and sub-committees. Draft standards on textile shrinkage tests and fireclay refractories have already been published. Apart from much detailed information the Bulletin contains the president's address to the general council and three very interesting general articles. The first of these, on the "Standard Atmosphere for Testing", compares average atmospheric conditions in India with those in other parts of the world and makes recommendations, which the Indian delegation was success. ful in getting accepted by the International Standards Organisation, for alternative 'standard atmospheres' to be adopted for use in industrial testing laboratories in tropical and temperate climates respectively. The second paper, on "Quality Control", is mainly a record of various conferences and papers relating to this subject, largely directed to its applications to the textile industry. The last paper deals with "Weights and Measures". It includes a brief summary of the past and present position in India, and puts forward a proposal for the adoption of the metric system with Indian names for the units, and a series of Indian prefixes and affixes to denote the successive powers (multiples and sub-multiples respectively) of 10. The Bulletin gives an impression of vitality which augurs well for the future success of the new organisation.

\section{Scientific Information in India}

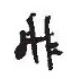

Commenting on the Royal Society's Conference on Scientific Information Services in London last year (see Nature, Angy 21, 1948, p. 279), the Journal of Scientific and Mdustrial Research (India) (Nos. 9 and $10,6 p 15,435 ; 1948$ ) emphasizes the importance fI sudh aids to research and the urgency of e volying a satisfactory system in India. It adce pts the view that the primary requirement is a cental organisation, maintaining liaison with similar organisations in other countries and directed by a man of science with width rather than depth of 